\title{
Chapter 25 \\ Ecosystem Models of Bivalve Aquaculture: Implications for Supporting Goods and Services
}

\author{
Jon Grant and Roberto Pastres
}

\begin{abstract}
In this paper we focus on the role of ecosystem models in improving our understanding of the complex relationships between bivalve farming and the dynamics of lower trophic levels. To this aim, we review spatially explicit models of phytoplankton impacted by bivalve grazing and discuss the results of three case studies concerning an estuary (Baie des Veys, France), a bay, (Tracadie Bay, Prince Edward Island, Canada) and an open coastal area (Adriatic Sea, Emilia-Romagna coastal area, Italy). These models are intended to provide insight for aquaculture management, but their results also shed light on the spatial distribution of phytoplankton and environmental forcings of primary production. Even though new remote sensing technologies and remotely operated in situ sensors are likely to provide relevant data for assessing some the impacts of bivalve farming at an ecosystem scale, the results here summarized indicate that ecosystem modelling will remain the main tool for assessing ecological carrying capacity and providing management scenarios in the context of global drivers, such as climate change.
\end{abstract}

Abstract in Chinese 本文重点关注通过生态系统模型的方法去理解双壳贝类 养殖活动与低营养级种群动力学之间的复杂关系。为此, 我们回顾了受双壳 贝类摄食影响的浮游植物空间显式模型, 并讨论了三个有关的实例, 包括河口 (Baie des Veys, 法国), 海湾 (特拉卡迪湾, 加拿大爱德华王子岛) 和海岸带开 放海域 (亚得里亚海, 艾米利亚-罗马涅沿岸, 意大利)。这些模型旨在为水产 养殖管理提供更深层次的信息, 但其结果也包含了浮游植物的空间分布和环 境压力下的初级生产力情况。我们或许可以通过新的遥感技术和原位传感器 远程传输的相关数据来评估生态系统规模的双壳贝类养殖造成的影响, 但所 有结果表明, 生态系统模型仍将是评估生态容量的主要工具, 并在气候变化等 全球范围影响的背景下提供养殖管理方面的参考信息。

\footnotetext{
J. Grant $(\bowtie)$

Department of Oceanography, Dalhousie University, Halifax, NS, Canada

e-mail: jon.grant@dal.ca

R. Pastres

Dipartimento di Scienze Ambientali, Informatica e Statistica, Mestre, VE, Italy

e-mail: pastres@unive.it
} 
Keywords Ecosystem modelling · Low trophic levels · Bivalve farming · Phytoplankton depletion · Aquaculture

关键词 生态系统建模 - 低营养级 - 双壳贝类养殖 - 浮游植物消耗 ・ 水产养殖

\subsection{Introduction}

The culture of marine suspension-feeding bivalves involves farming extensive coastal areas at high biomass. The ability of these animals to influence ecosystem processes is a central theme of this book. Ecosystem goods and services, such as provision of harvested protein, require that energy or matter flow be directed through cultured populations, and potentially diverted from other pathways (e.g. wild species requirements). The concept of carrying capacity has been subdivided to reflect this definition (McKindsey et al. 2006). For example, ecological carrying capacity would apply to an environmental threshold beyond which the ecological integrity of the ecosystem would be considered compromised. This approach requires assessment of inputs and outputs of matter and energy to coastal systems, and ecosystem modeling has frequently been utilized for this purpose (Grant and Filgueira 2011).

Ecosystem models applied to shellfish culture may be categorized in two ways:

1. Mitigation models, which seek to address the role of bivalves in reducing 'excess' phytoplankton arising from eutrophication. This topic is addressed explicitly in Petersen et al. (2019).

2. Carrying capacity models, which seek to determine food limitation of cultured bivalves. This chapter is addressed from a provisioning point of view in Smaal and van Duren (2019).

In both cases, the concentration of phytoplankton biomass, usually quantified as photopigments, primarily chlorophyll, has been the focus of ecosystem models. Phytoplankton are at the base of all marine food webs, and may be characterized as the most important part of marine ecosystems, and certainly the most important of supporting services (Richardson and Shoeman 2004). Regulation of phytoplankton biomass classically occurs through either bottom up (nutrients) or top down (grazing) processes. The biomass of natural bivalve populations is equilibrated with its food supply, so excessive grazing would not be an ongoing feature of the ecosystem. However, bivalves stocked in culture could easily overgraze their food supply, the essence of carrying capacity. Several consequences would ensue, including reduced growth or increased mortality of farmed animals, and competition with other grazers such as wild bivalves and zooplankton. In order to preserve the supporting service of phytoplankton, criteria have been established based on the abundance of phytoplankton that should be 'left over' once bivalve nutrition is satisfied. Grant and Filgueira (2011) argued that the extent of depletion should not exceed the natural 
spatiotemporal variation of phytoplankton in a given culture system, effectively parameterizing a sustainability criterion.

Although this value can be expressed as an average, the spatial distribution of phytoplankton can be very complex, as well as the biological and physical processes that lead to its renewal. In bays and estuaries, exchange with the coastal ocean has a large influence on phytoplankton, as does grazing and sinking (Cloern 1996). Moreover, watershed-derived nutrients are a key factor in phytoplankton production, as occurs in eutrophication (Cloern 2001). Despite numerous studies of phytoplankton in estuaries, there are few which attempt to map their spatial distribution.

Sampling to create those maps is difficult due to temporal variation at very small spatial scales. Although quantities such as phytoplankton may be expressed as chlorophyll and observed through satellite remote sensing, there are several drawbacks to this approach. First, coastal bays are not ideal for ocean colour measurements since pixel resolution may be coarse, and many pixels are masked due to land proximity, water depth, and turbidity. Despite this limitation, Radiarta and Saitoh (2009) were able to detect both spatial and temporal patterns of chlorophyll and turbidity in Funka Bay (Japan), although the $1 \mathrm{~km}$ resolution was appropriate to the $\sim 300 \mathrm{~km}$ scale of the bay. Moreover, the impact of bivalves on chlorophyll cannot be easily observed, despite one example from a high resolution CASI image (Grant et al. 2007). Some of these limitations may be overcome in the near future as the spatial and temporal resolution of satellite data increase. Furthermore, at local scales it may become possible to use underwater or aerial autonomous vehicles equipped with ocean colour sensors for detecting phytoplankton depletion due to the presence of shellfish farms (Ludvigsen and Sorensen 2016). Quantification of local depletion has been accomplished with towed sensors (Nielsen et al. 2016).

Modelling is perhaps the only way to address these processes at larger scales and produce maps of chlorophyll simulated in the presence and absence of aquaculture, as well as in alternative management scenarios, e.g. relocation of farms, changes in stocking density, and introduction of new species. Modelling is also the only option for exploring the consequences of climate change on shellfish production, as shown in Canu et al. (2010) and Guyondet et al. (2015). Although model simulations can create detailed spatial maps, they are difficult to validate, especially the null scenario in the absence of shellfish at an established aquaculture site. In fact, in many cases, the consequences of siting shellfish leases in terms of chlorophyll are retrospective - extensive bivalve aquaculture is already in place. There are few examples where aquaculture site planning has been carried out on the basis of predicted phytoplankton spatial distribution (Filgueira et al. 2015). We suggest that the necessity of understanding food limitation in cultured bivalves has advanced an understanding of phytoplankton distribution in general, as well as models to elaborate this occurrence.

Based on these considerations, we review spatially explicit models of phytoplankton impacted by bivalve grazing and pose the following questions: 
- How has ecosystem modelling been used to map chlorophyll in the presence and absence of bivalve culture?

- Are phytoplankton submodels used for this purpose adequate?

- Are these maps representative of ecosystem-scale properties?

\subsection{The Structure of Ecosystem-Wide Depletion Models}

Most models of the interaction between suspension feeders and phytoplankton are classical PNZ models with varying degrees of complexity in trophic structure (see review in Grant and Filgueira 2011). These range from simplified models where there are no other grazers except cultured bivalves, to more fully configured pelagic food chains. Although these ecosystem models can be simulated over an annual cycle, they are more commonly used to represent spring and summer for purposes of emphasizing spatial over temporal changes. This occurs because the focus is primarily on explicit aquaculture locations and the local or regional spatial impacts of grazing on phytoplankton. This focus is opportune because the case of "no grazers' must inevitably act as reference point which yields insight into the dynamics of coastal phytoplankton.

Because interannual variation in seasonal forcing such as precipitation and river flow have such large impacts on phytoplankton production, it is possible to understand longer term trends in food supplies which might influence bivalve production (Grangeré et al. 2009; Thomas et al. 2011). However, depending on the importance of top down regulation, models which neglect other grazers such as zooplankton might be expected to perform poorly in simulating annual phytoplankton cycles. Nonetheless, if suspension feeding bivalves pre-empt zooplankton grazing pressure, annual phytoplankton cycles will reflect predation by shellfish since aquaculture is persistently in place and forces temporal changes based on harvest and stocking. These changes in phytoplankton production have been observed in San Francisco Bay due to an invasive suspension feeding clam (Cloern 1982). Regardless, the dominance of bivalves in controlling phytoplankton is also dependent on the spatial extent of aquaculture in the system. Below, we present case studies where bivalve culture is spread throughout a bay (Canada), where it is localized in a semi-enclosed system (France), and where it occurs along a stretch of open coast (Adriatic Sea, Italy).

\subsection{Phytoplankton in Estuaries - Distribution}

Due to the importance of eutrophication and of phytoplankton in estuarine food chains, there is a substantial general literature on this topic. However, fewer studies deal with spatial distribution of phytoplankton, and as indicated above, remote sensing of chlorophyll is difficult in these environments. Moreover, there are few models of phytoplankton that attempt to simulate relatively small-scale spatial detail, including the effects of river, tide, wind, bathymetry, etc. However, we reiterate that 
due to the importance of microalgal distribution for aquaculture success, models of seston depletion by shellfish have provided general insight into the topic of phytoplankton ecology.

Information on spatiotemporal variation in phytoplankton is significant in being able to characterize the 'normal' range of biomass or chlorophyll, so that grazer perturbations due to aquaculture may be gauged. The spatial distribution of phytoplankton is partially a balance between primary production and advection; these dynamics are explored in the case studies below. Although photosynthesis allows phytoplankton biomass to accumulate, advection may either contribute to this buildup as in convergence zones, or act to disperse cell populations and reduce local biomass (Cloern and Nichols 1985; Lucas et al. 1999a, b).

Photosynthesis is a result of both nutrient supply and the light field, both of which are highly variable in coastal systems. The role of rivers in supplying nutrients to estuaries has been extensively studied due to the prevalence of eutrophication (Cloern 2001). The impact of bivalve aquaculture in modulating these processes through grazing has also been long recognized (Meeuwig 1999) and utilized in bioremediation programs (see Cranford 2019; Petersen et al. 2019). Turbidity may impose serious limits on photosynthesis (May et al. 2003) and typically occurs in bivalve culture areas which are shallow, dominated by soft sediments, and thus subject to resuspension.

\subsection{Phytoplankton in Estuaries - Composition}

While we have emphasized in this chapter the effects of bivalves on chlorophyll as a bulk biological water property, this is clearly an over-simplification. Phytoplankton undergo a seasonal succession of species composition described by Cloern (1996) as follows: 'A common annual cycle begins with large winter-spring diatom blooms followed by summer blooms of small flagellates, dinoflagellates, and diatoms and then autumn blooms dominated by dinoflagellates'. The selectivity of bivalve grazers for certain classes of microalgae is well known and selection not only removes bulk chlorophyll but creates a preponderance of small cells referred to as picoplankton $(>2-3 \mu \mathrm{m})$ (Smaal et al. 2013; Zhao et al. 2016). Size-selective feeding in bivalve culture can influence the entire phytoplankton size spectrum in coastal waters as documented in multiple studies (Cranford et al. 2011). It has been further suggested that this alteration may be an indicator of carrying capacity for bivalve aquaculture (Cranford et al. 2008; Jiang et al. 2016). Cultured bivalves can, however, derive significant nutrition from picoplankton (Sonier et al. 2016), so their indicator value is not straightforward.

From an aquaculture modelling perspective, multiple classes of phytoplankton are less commonly implemented in favour of the more tractable unimodal phytoplankton component, expressed solely as chlorophyll, with non-specific size and species composition. In the example below, Grangeré et al. 2010 focus on diatoms as the dominant phytoplankton class in Baie des Veys but found that modelled 
chlorophyll was underestimated due to Phaeocystis blooms which were not part of the simulation. However, because this genus is colony forming, its value as oyster food is variable, thus impacting model chlorophyll predictions but not necessarily bivalve feeding. It is feasible that high levels of chlorophyll could occur in ecosystems controlled by bivalve grazing where there are an abundance of picoplankton with a size refuge from suspension feeders (e.g. Comeau et al. 2015). Although there are bivalve ecosystem models with several phytoplankton size/composition classes (Cugier et al. 2010; Brigolin et al. 2011; Guyondet et al. 2015), this is more often formulated for temporal succession of phytoplankton rather than spatial distribution of size classes. The topic of harmful algal blooms (HAB) is essential in any discussion of coastal phytoplankton composition and shellfish culture. It is beyond the scope of this chapter and is covered in Wijsman et al. 2019.

\subsection{Case Studies}

We utilize only case studies where a map of modelled chlorophyll is depicted, rather than a change map (i.e. \% depletion), since the 'no bivalves' case requires these units. However, it is recognized that even with this restriction, there are many more examples than can be covered herein.

\subsubsection{Baie des Veys}

A series of studies based on the Normandy Coast of France represent among the most comprehensive examples of chlorophyll models applied to bivalve culture. We discuss Grangeré et al. (2010), conducted in the Baie des Veys. This is a funnel shaped sub-estuary in the eastern Baie de Seine including the entrance of four rivers dominated by the Vire River. Due to macrotidal conditions, there are extensive tidal flats which include wild cockle populations. The primary culture species is Pacific oyster, Crassostrea gigas, grown on intertidal oyster tables, but Mytilus edulis is also farmed.

A significant part of this study is the extent to which the phytoplankton submodel was calibrated, largely by comparing modelled and measured primary production (Grangeré et al. 2009). Specifically, a variety of photosynthesis-intensity (PI) curves were generated for the Baie des Veys and compared to field observations of primary production $\left({ }^{14} \mathrm{C}\right.$ method) and light. Consideration of both $\mathrm{C}$ : Chl and nutrient limitation formulations was also made. Because the calibrated phytoplankton submodel was used in Grangeré et al. (2010), this study represents a comprehensive examination of their spatial and temporal distribution.

Model results indicate that phytoplankton production is stimulated in the spring by river nutrient input, first appearing on the western side of the bay, and proceeding until the head of the bay has enhanced chlorophyll (Fig. 25.1b). Pigment levels 

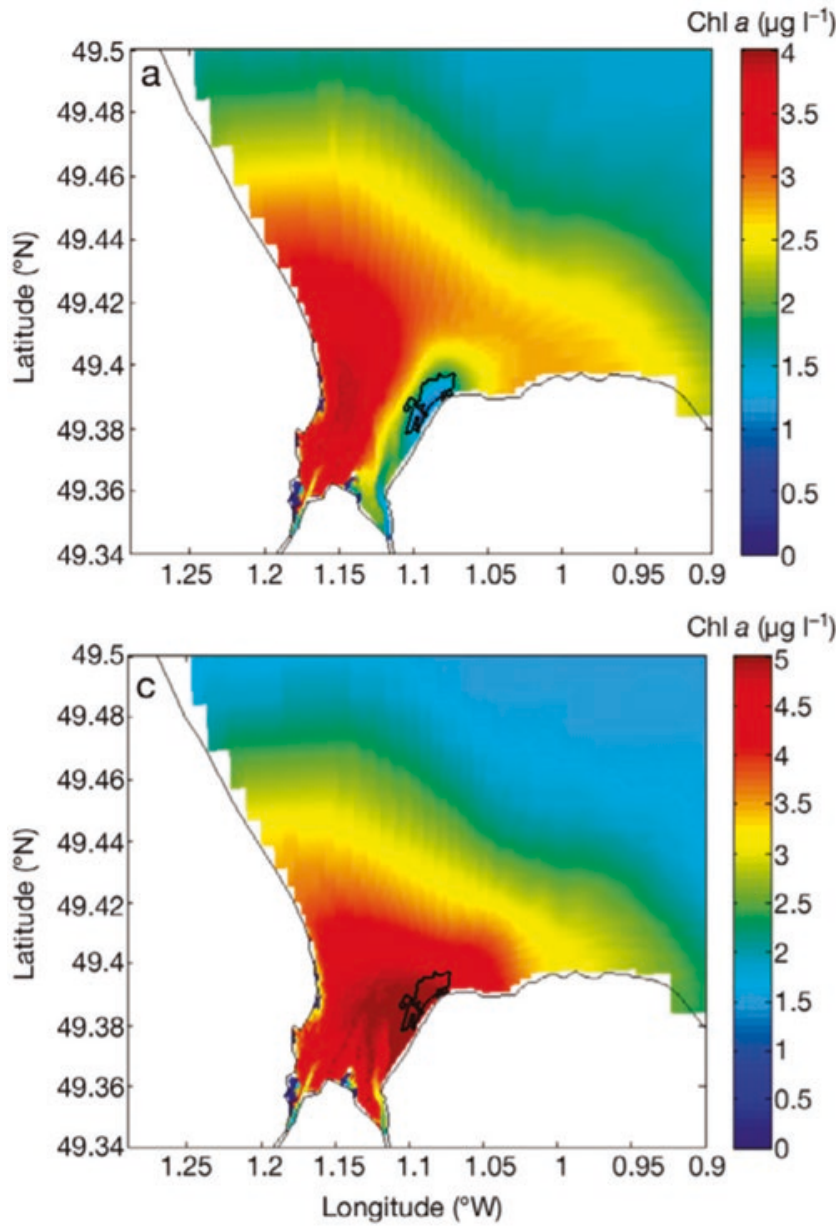

Fig. 25.1 A comparison of ecosystem scale chlorophyll distribution in the Baie de Veys, Normandy in the presence (a) and absence (b) of suspension feeding benthos (cultured and wild). The oyster farming area is shown in black outline

gradually attenuate offshore presumably through mixing. This appears to be a somewhat classical bottom-up scenario for a phytoplankton bloom. The simulation that includes oyster aquaculture shows a strong influence of bivalve grazing, with chlorophyll depleted by a factor of about threefold in the culture area (Fig. 25.1a). Finer scale views of the oyster culture areas revealed additional structure, with oysters at the northern limit of the culture area achieving superior growth due to better advective renewal of seston. As Grangeré et al. (2009) state "Top-down effects of oysters on phytoplankton at local scales were revealed, whereas bottom-up effects drove primary productivity at the whole bay scale. In general we conclude that spatial 
modelling is particularly appropriate to reveal spatial properties which would be difficult to observe directly."

It is important to emphasize that their model was applied to the seasonal dynamics of oyster growth, and not an instantaneous or averaged assessment of carrying capacity. The results of their studies indicate several principles for resolving shellfish-food chain interactions at the ecosystem scale:

1. An ecosystem model with sufficient spatial scale and appropriate structure to account for processes forced by an offshore boundary as well as a land-based source of nutrients, i.e. rivers

2. Validation of the phytoplankton model parameters and groundtruthing of chlorophyll via water samples.

3. The ability to distinguish between classes of phytoplankton, including those that are rejected by suspension feeding bivalves for either size or composition.

4. Clear delineation of bivalve culture areas, and the importance of their spatial extent in forcing localized versus far field chlorophyll distribution.

\subsubsection{Tracadie Bay, Prince Edward Island, Canada}

Prince Edward Island (PEI) has the largest mussel aquaculture industry in North America, producing 19,000 tonnes annually. Much of the province is characterized by shallow sandy river estuaries, ideal for shellfish farming. Multiple studies have been conducted on the North Shore of the Island in Tracadie Bay (see references in Filgueira et al. 2015), but we highlight the spatial model in Grant et al. (2008). The bay is characterized by a barrier island at the entrance to a small inlet with a complex tidal delta, and a gradual narrowing over its $5 \mathrm{~km}$ length. The Winter River enters into a small side bay. Mussels (Mytilus edulis) are cultured on longlines in most of the bay, excluding the inlet region with a large intertidal zone. The ecosystem model in Grant et al. (2008) included dissolved nutrients, phytoplankton, detritus, and mussels coupled to a 2D circulation model with 606 nodes. The phytoplankton submodel is forced by light and nutrients. The daily and annual light fields were also modelled with respect to latitude according to Grant et al. (1993) Nutrient fields were available from a sampling program on the Winter River described in Cranford et al. (2007).

The example output (Fig. 25.2) demonstrates both the dynamics of chlorophyll (expressed as carbon equivalents) as well as the effects of grazer control. In this summer example without mussels, exchange at the inlet locally dilutes chlorophyll, but a gyre region behind the barrier island allows phytoplankton to accumulate with the benefit of a continual offshore nutrient renewal. However, this effect gradually tapers off through the interior region as reduced flushing causes nutrient limitation and reduced biomass. About midway along the length, entrance of Winter River nutrients causes localized increases in chlorophyll, an effect that is more pronounced in spring (not shown) when river nutrients are higher. Tracadie Bay is surrounded by 


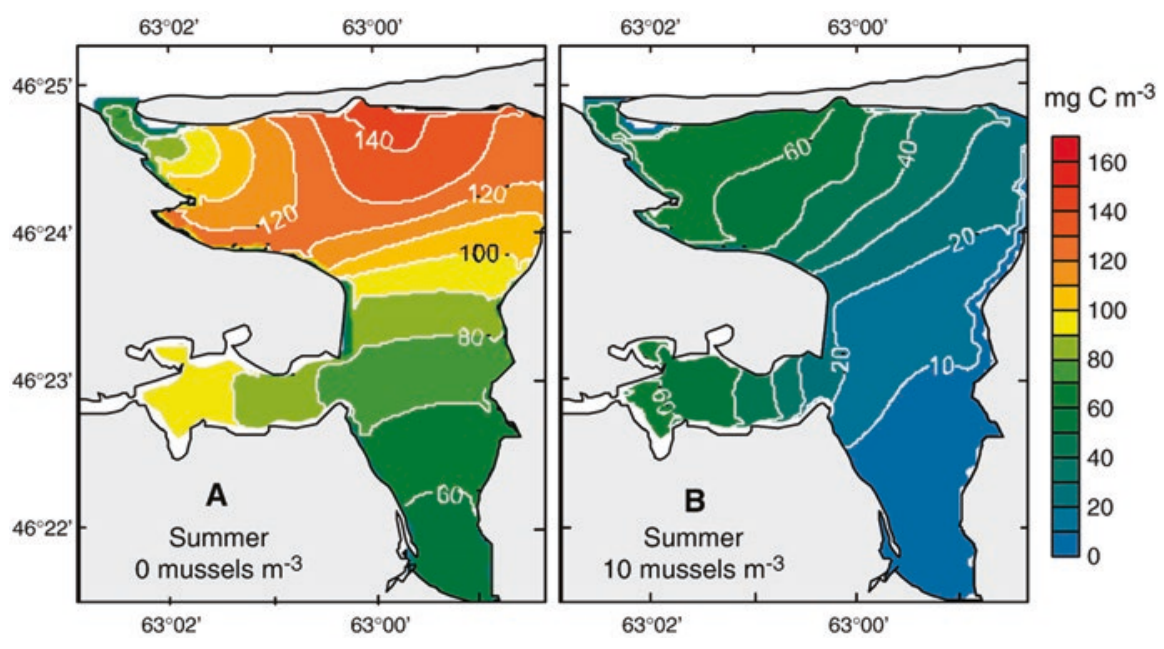

Fig. 25.2 Modelled chlorophyll carbon maps of Tracadie Bay, Nova Scotia in the presence and absence of cultured mussels. Units are carbon equivalents of PEI biomass converted with $\mathrm{C}: \mathrm{Chl}=50$

agriculture (as are many estuaries in PEI), and the potential eutrophication is only offset by mussel grazing (Cranford et al. 2007; Guyondet et al. 2015; Meeuwig 1999).

The effects of mussel grazing on this system are dramatic. There is a reduction in chlorophyll of 2-6x. The effect of the gyre behind the barrier as a chlorophyll sink is eliminated and the sharp landward reduction in chlorophyll is even more pronounced. Although the local inlet area is not subject to depletion due to tidal exchange, the rest of the bay has chlorophyll levels that are less than any location in the absence of mussels.

This study is unique in that a towed fluorometer (Acrobat) was available to groundtruth model results. While Acrobat data basically validated model predictions, it also demonstrated a tidal signal in depletion as Winter River emptied its high biomass to the larger bay at low tide. These field results illustrate the contrast that observations, including sampling and remote sensing, are snapshots whereas models are averaged, in this case daily.

The ultimate field experiment in Tracadie Bay was conducted in December 2009 when a winter storm opened a new tidal inlet along the barrier island (Filgueira et al. 2014). Water renewal time for the whole bay was reduced by $1 / 3$ or more. As a result, cultured harvest increased by about $1 / 3$ even with the same mussel stocking density. The alleviation of seston depletion by flushing was clearly demonstrated. Moreover, the effects of climate change on coastal geomorphology were expressed through increased estuarine productivity.

Model outcomes provide the following generalities: 
1. The ability of shellfish aquaculture to dominate chlorophyll spatial distribution in a small bay.

2. The importance of flushing and renewal as a mitigation against seston depletion.

3. The use of sophisticated spatial survey methods to groundtruth model results

4. The success of a one-class phytoplankton model

\subsubsection{Adriatic Sea, Emilia-Romagna Coastal Area, Italy}

The two previous case studies emphasize pelagic dynamics with bivalves as primary consumers. However, the shallow waters characteristic of bivalve culture areas invariably involve tight benthic-pelagic coupling. Benthic processes have been studied extensively in both the Baie des Veys and Tracadie Bay (e.g. Cranford et al. 2009; Ubertini et al. 2012), but we use an example from Adriatic Italy to bring together benthic and pelagic dynamics as they relate to suspended bivalve culture.

Shellfish culture is an important activity along the Adriatic and Ionian Italian coasts. The two main products are: (i) Manila clams (Tapes philippinarum), which are farmed in the Northern Adriatic lagoons, such as those of Marano, Venice, Goro and Scardovari, and (ii) Mediterranean mussel (Mytilus galloprovincialis), which

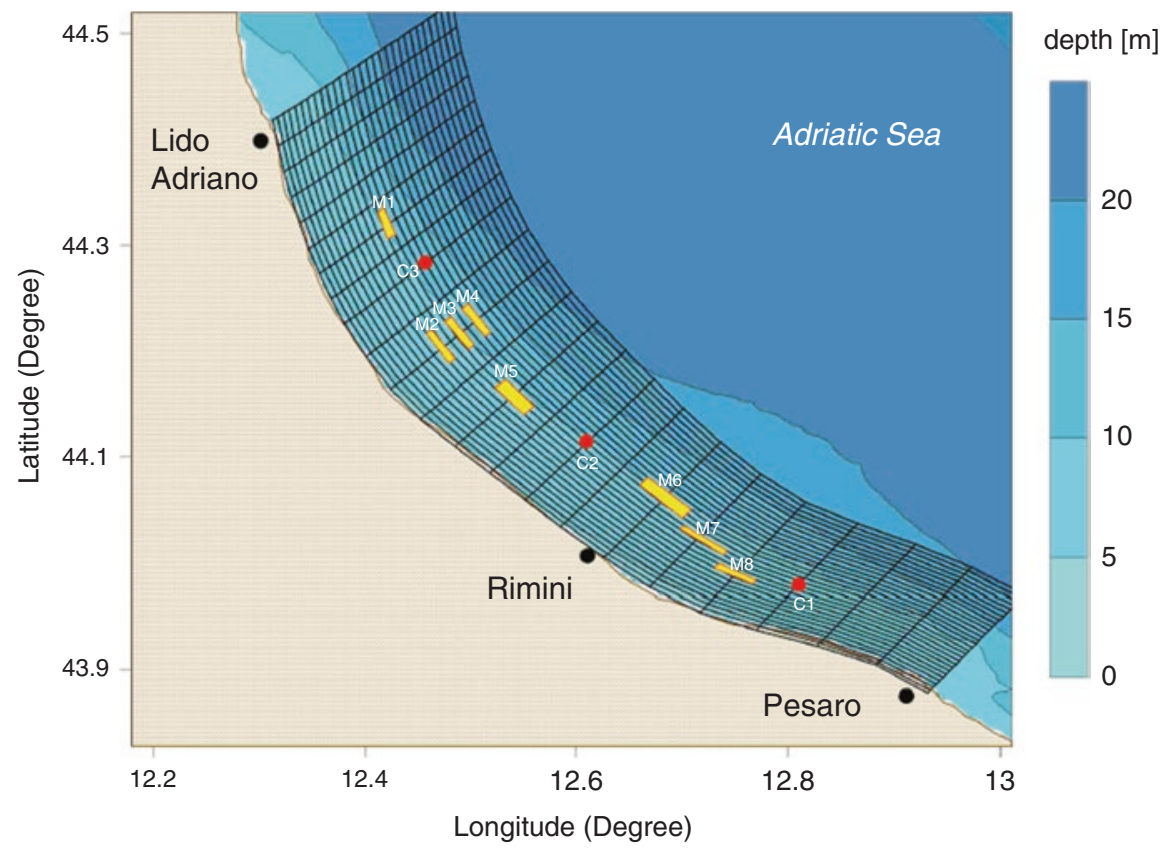

Fig. 25.3 Map of the coastal area investigated in the case study. Water quality monitoring stations are shown in red, mussel farms in yellow 
are farmed mainly off-shore on longlines from the Gulf of Trieste in the North to the Gulf of Taranto in the South. This case study, presented in detail in Brigolin et al. (2008), was focused on investigating the impact of mussel farming on lower trophic levels and on the biogeochemistry of surface sediments along the coastal area of Emilia-Romagna (Fig. 25.3), which in 2013 produced about 22,000 tonnes of Mediterranean mussels, i.e. about one third of the Italian production. This study differs from the previous cases as it deals with an open, though shallow, coastal area where processes driven by the North-South WACC (Western Adriatic Coastal Current) are effectively transported along the coast, mixing dissolved compounds and suspended particles.

The above issues were investigated using an integrated model (Brigolin et al. 2008), which included: (1) a 2D transport module, (2) a pelagic biogeochemical module, (3) a farmed mussel population dynamics module, (4) a module for the simulation of early diagenesis processes in surface sediments. The model was designed to simulate the population dynamics of farmed mussels and their impact on the pelagic environment, as well as on the fluxes of oxygen and nitrogen due to the remineralization of mussel faeces and pseudo-faeces in surface sediment. Therefore, it can be used for estimating the biomass yield and quantifying the effect of seston depletion due to mussel filtration as in Dowd (2005), Grant et al. (2005), and Ferreira et al. (2007). Furthermore, the explicit inclusion of early diagenetic processes allows assessment of the influence of mussel farming on the overall $\mathrm{C}$ and $\mathrm{N}$ biogeochemical cycles. This context expands the more pelagic focus of the Canadian and French case studies, as well as expanding the community composition of the phytoplankton submodel.

The first module solves the advection-diffusion equation. Input data for water velocities and elevation were provided by a $2 \mathrm{D}$ finite difference hydrodynamic model, which was previously calibrated to simulate the hydrodynamic circulation in the NW Adriatic Sea under realistic forcings induced by tides and meteorological fields for the year 2004 (Lovato et al. 2010). The hydrodynamic model was applied to the whole Adriatic, including the Lagoon of Venice, using a curvilinear boundaryconforming grid, composed of 287,363 nodes, with mesh sizes varying from approximately $12 \mathrm{~km}$ to $50 \mathrm{~m}$.

The pelagic biogeochemical module, described in detail in Brigolin et al. (2011), included 14 state variables in order to simulate the dynamics of carbon, nitrogen (nitrate, ammonia), phosphorus and silica, and to mimic the main features of the observed seasonal succession of the phytoplankton community. Therefore, besides the concentrations of the above inorganic nutrients and dissolved oxygen, the module simulates the evolution of three phytoplankton functional types: winter diatoms, summer diatoms and flagellates. The set of state variables also includes four pools of dissolved organic detritus, one for each macronutrient. Beside allowing closure of biogeochemical cycles, the carbon detritus represents an additional source of energy for farmed mussels, which in some instances can compensate for the lack of phytoplankton (Brigolin et al. 2009). Diatoms were divided into winter and summer types as winter diatom blooms are mainly accounted for by Skeletonema marinoi, while autumn peaks are related to the presence of Chaetoceros socialis and other 
Chaetoceros spp. The flagellate functional type was meant to model various classes (Prasinophycea, Haptophycea, Chlorophycea, Cryptophycea, and Chrysophycea). Zooplankton variables were defined according to size, in order to take into account the role of micro- and meso-zooplankton in controlling phytoplanktonic biomass. The above biotic variables were expressed as carbon content of planktonic tissue. Elemental fluxes of N, P and Si through the ecosystem are quantified by assuming a fixed C:N:P:Si ratio.

The third module was based on the individual bioenergetic model described in detail in Brigolin et al. (2009), which simulates the evolution of dry weight, and through correlation, wet weight and length of an average Mediterranean mussel (Mytilus galloprovincialis) individual. The population dynamics of cohorts of farmed mussels at each farming site were simulated by following the evolution of an ensemble of individuals by means of a Monte Carlo approach. The parameterization of each individual was slightly different in order to mimic the observed variability of the output variables. In particular, the maximum clearance rate CRmax and the maximum respiration rate Rmax, were treated as Gaussian stochastic variables and randomly assigned to each individual. Mortality rate was assumed to be constant throughout the grow-out phase. The daily release of mussel bio-deposits from a given mussel farm was subsequently estimated on the basis of individual emissions and stocking density. Mussel biodeposits were transported using a Lagrangian particle tracking module, which was originally developed for investigating the impact of fish farming on the benthic community and tested at Mediterranean fish farms (Brigolin et al. 2014). The module was recently updated and employed for mapping the environmental impact of shellfish farms, as part of a systematic procedure for assessing the suitability of this coastal area for oyster and mussel farming, applied in the context of the Maritime Spatial Planning EU Directive (Brigolin et al. 2017).

Mussel biodeposits and organic detritus derived from the decomposition of phyto and zooplankton eventually settle on the seabed; this flow of organic matter to surface sediments represents the input for the early diagenesis module, which enables estimation of the steady-state vertical profile of ammonia, nitrate and reactive phosphorus in a sediment core. Early diagenesis processes are presented in detail in Brigolin et al. (2011); they include the oxic degradation of organic matter, as well as the main anoxic pathways, in which microbial communities use nitrate, sulfate, and oxidized forms of iron and manganese as electron acceptors. Re-oxidation processes of reduced products are also taken into account, since they contribute to depletion of dissolved oxygen concentration in the upper sediment layers.

Setting boundary conditions for an open coastal area is not easy and there are always sources of uncertainty. Boundary conditions for the pelagic model were estimated on the basis of a year long time series of sea surface temperature and concentrations of ammonium, nitrate, dissolved inorganic phosphorus, dissolved oxygen, reactive silica and chlorophyll collected approximately every 2 weeks at 6 monitoring stations close to the boundary of the computational domain.

The results of this study indicate: 


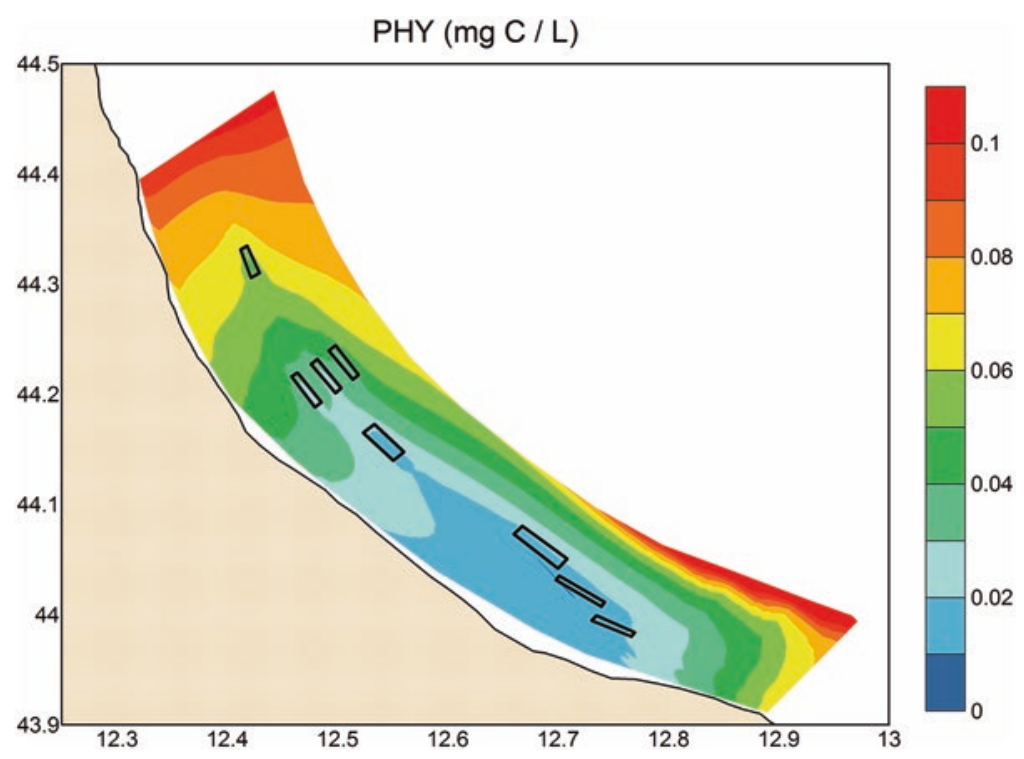

Fig. 25.4 Spatial distribution of chlorophyll in the Emilia-Romagna study area (Italy) in Spring 2004. Units are $\mathrm{mg} \mathrm{Cl}^{-1}$

1. As shown in Fig. 25.4, the model predicts different mussel biomass yields caused by a north-south chlorophyll gradient (expressed as $\mathrm{mg} \mathrm{Cl}^{-1}$ ) related to the nutrient enriched waters discharged by the Po River.

2. Local depletion of chlorophyll by cultured mussels could not be unequivocally related to the presence of the farms, even though Fig. 25.4 suggests that mussel filtration in spring could locally reduce phytoplankton density, particularly in the northern part of the study area. In this regard, increasing the spatial resolution of the model could help in improving the description of transport and mixing processes and their role in ecosystem dynamics.

3. The effects of mussel farms on phytoplankton biomass and $\mathrm{C}$ and $\mathrm{N}$ cycles are more clearly revealed in Fig. 25.5, which compares the deposition of organic particles per unit surface beneath mussel farms with those estimated at control sites (Fig. 25.3). The fluxes of organic carbon at the sediment-water interface are similar beneath farms M1-M6 and about 8 times higher than those at control sites. Even though these deposition rates are much lower in comparison with those originated in sea-cage fish farming, the overall impact of mussel farming on the $\mathrm{C}$ and $\mathrm{N}$ cycles may be more significant at a regional scale, because of the much larger extent of leased areas. Furthermore, fluxes of organic carbon are significantly lower beneath farm M7, which is located in between farm M6 and M8, in the southern part of study area. Since these fluxes are correlated with the amount of phytoplankton and non-living organic particles cleared by mussels, this result provides indirect evidence of phytoplankton depletion, due to the cumulative effect of the adjacent farms in clearing suspended particles. 


\section{BIODEP}

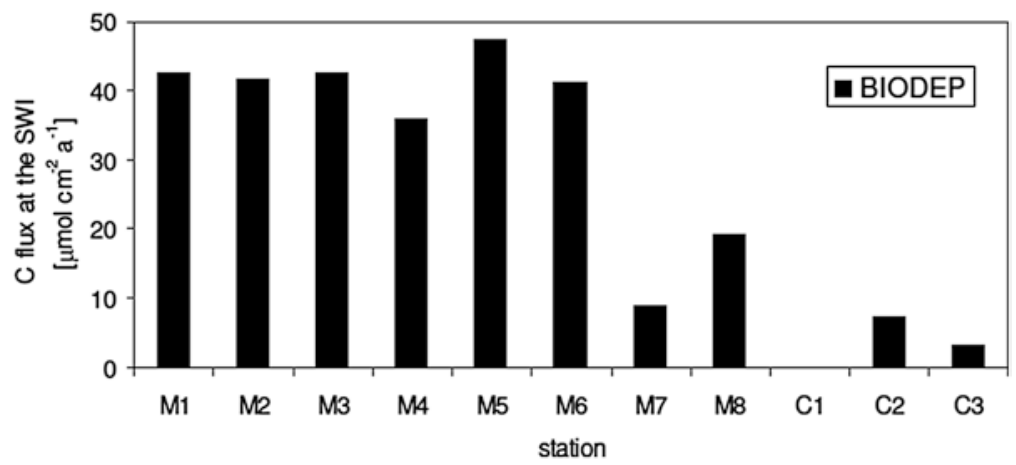

Fig. 25.5 Annual fluxes of organic carbon in surface sediment beneath the mussel farms located in the Emilia-Romagna study area and at the three monitoring stations shown in Fig. 25.3, which can be taken as control sites

4. The model can be used for assessing the overall "ecological carrying capacity" of the coastal zone with respect to mussel farming and is thus a useful tool for managing this activity within an Integrated Coastal Zone Management approach. Patterns and levels of biodeposition provide evidence of the spatial pattern of bivalve grazing in a way that would not be indicated by chlorophyll depletion.

5. The value of both benthic and pelagic processes in modelling bivalvephytoplankton interactions is clearly shown, as the feedback to nutrient regeneration has implications for phytoplankton production, including favouring certain cell types (Zhao et al. 2016).

\subsection{Management and Husbandry Considerations}

The implications of spatial scale for shellfish culture are immediately obvious. In the case of Baie de Veys, culture density is limited to the intertidal, excluding huge areas of the bay. For this reason, it would be difficult for aquaculture to cause ecosystem-wide depletion (see also Dabrowski et al. 2013). However, this does not preclude the significance of more localized depletion, which is obvious from model results. Moreover, this depletion causes local variation in oyster growth including depressed growth in the chlorophyll depletion zone. In contrast, the case study of Tracadie Bay indicates system-wide seston depletion. In this example, mussel culture on suspended longlines is practiced throughout the bay, and thus culture occupies much of the surface area. Consequently, baywide seston depletion occurs, and diminishes mussel growth in the upper parts of the bay where renewal of depleted water is reduced (Waite et al. 2005). 
The results presented in the Adriatic case suggest that even in open coastal areas the cumulative impact of shellfish farms on phytoplankton dynamics should be taken into account when estimating both the ecological and production carrying capacities. However, these findings should be interpreted with care due to: (i) the rather coarse resolution of the model, (ii) the uncertainty in ocean boundary conditions, whose effect on the results is more relevant than in the other two case studies here presented. Those issues are to some extent related, and they can be tackled in future studies by nesting coastal models within models developed for operational oceanography and using higher resolution ocean colour products. In this regard, the Copernicus Marine Environment Monitoring Service (http://marine.copernicus.eu/) is already providing reanalysis and real-time data concerning both water temperature and biogeochemical variables.

Given that some culture scenarios cause system reduction of chlorophyll, questions of standards and thresholds quickly arise. For this reason, many results are reported as the spatial distribution of \% depletion (Filgueira et al. 2015). This format is important because it specifies a map of depletion and its degree of localization. Even when large-scale aquaculture scenarios are compared with models (Filgueira et al. 2013), it is obvious that some culture densities are beyond carrying capacity as defined by depletion thresholds.

The utility of chlorophyll maps in aquaculture planning has recently emerged in modelling studies. Filgueira et al. (2010) used a simplified mussel-phytoplankton model in a Norwegian fjord where an upweller was used to stimulate phytoplankton production via nutrient diffusion. They deployed optimization to indicate culture locations which minimized advective loss of enhanced chlorophyll. Subsequently, Filgueira et al. (2015), answered a planning question regarding the severity of depletion under proposed additions of mussel culture longlines into a bay with existing aquaculture leases.

We subscribe to an ecosystem approach to aquaculture (EAA) as promulgated by Aguilar-Manjarrez et al. (2017). This is consistent with our stated goal of maintaining ecosystem services within their natural limits (Grant and Filgueira 2011). These limits expressed as temporal variation is site dependent (e.g. Thomas et al. 2011; Cloern and Jassby 2010) and a discussion of intra-annual variation is beyond the scope of this chapter. When aquaculture is discretely located, i.e. single farm sites, effects produced including nutrient release or biodeposition tend to be near-field. In this case, scaling of the magnitude of these effects relative to the size of the ecosystem is essential, even though this is rarely considered. In the case of shellfish culture, effects such as depletion of chlorophyll tend to be pervasive, even impacting large scale phytoplankton spatial distribution as in Tracadie Bay. As shown in the Adriatic case, spatial patterns of biodeposition and subsequent diagenesis are also apparent. Even though new remote sensing technologies and remotely operated in situ sensors are likely to provide relevant data for assessing some of these impacts, we emphasize that ecosystem modelling will remain the main tool for interpreting these processes, assessing ecological carrying capacity and providing management scenarios in the context of global drivers, such as climate change. The Tracadie Bay case of a new inlet is a graphic example (Filgueira et al. 2014). 
Conservation of primary production by microalgae, the most important of supporting services, can thus be managed with respect to aquaculture development. Modelling has been underutilized in marine spatial planning applied to aquaculture, but has huge scope for furthering the EAA approach, as in Brigolin et al. (2017) and Filgueira et al. (2015). Although we highlight the value of these models in their ability to elucidate the spatial dynamics of phytoplankton, several questions arise as to why the models work so well in terms of simulating both bivalve growth and chlorophyll distribution.

For example, size composition of phytoplankton seems to be an ecosystem-wide response of differential grazing. However, spatial variation in phytoplankton communities may be difficult to characterize with sampling (see Zhao et al. 2016). Although remote sensing has been used to distinguish taxonomic makeup of autotrophs including size classes (Brewin et al. 2011) the problems of ocean colour detection in the coastal zone persist.

In conclusion, we pose a few questions in the context of how they might impact model structure and predictive power, with a suggestion for the direction of answers, recognizing that these are very much topics for future research.

What are the consequences to other grazers for changes in phytoplankton size distribution? Comeau et al. (2015) examined partitioning of particle sizes between cultured bivalves and tunicates, and assessed the extent to which tunicates 'removed' carrying capacity through grazing competition.

What is the role of aggregation in masking apparent size classes? Feeding experiments demonstrate that small cells are readily ingested when embedded in mucus aggregates (Kach and Ward 2008; Cranford et al. 2011), but aggregate size structure, their incorporation of phytoplankton, and implications for bivalve food models are poorly known.

Why isn't resuspension more important in these shallow systems and thus necessary in models? There is an extensive literature showing positive, negative, or neutral effects of resuspension in bivalve growth (e.g. Grant et al. 1990; Kang et al. 2006; Ubertini et al. 2012). This likely occurs because, despite the potential for entrainment of benthic microalgae into suspension, excess suspended load dilutes seston quality. Although similar questions have been posed for detritus as a supplemental food source (e.g. macrophyte debris), the bivalve-phytoplankton trophic link is unquestionably central to food limitation and carrying capacity for aquaculture species.

Acknowledgements The authors are grateful to the referees for their valuable comments.

\section{References}

Aguilar-Manjarrez J, Soto D, Brummett R (2017) Aquaculture zoning, site selection and area management under the ecosystem approach to aquaculture. Full document. Report ACS113536. Rome, FAO, and World Bank Group, Washington, DC, 395 pp 
Brewin RJW, Hardman-Mountford NJ, Lavender SJ, Raitsos DE, Hirata T, Uitz J, Devred E, Bricaud A, Ciotti A, Gentili B (2011) An intercomparison of bio-optical techniques for detecting dominant phytoplankton size class from satellite remote sensing. Remote Sens Environ 115:325-339

Brigolin D, Lovato T, Ciavatta S, Pastres R (2008) The impact of mussel farming on the biogeochemistry of the northern Adriatic coastal ecosystem: preliminary results from a modelling study. ICES CM Documents 2008 of the ICES 2008 annual science conference, Halifax, Canada, Document CM 2008/L:12

Brigolin D, Dal Maschio G, Rampazzo F, Giani M, Pastres R (2009) An individual-based population dynamic model for estimating biomass yield and nutrient fluxes through an off-shore mussel (Mytilus galloprovincialis) farm. Estuar Coast Shelf Sci 82:365-376

Brigolin D, Lovato T, Rubino A, Pastres R (2011) Coupling early-diagenesis and pelagic biogeochemical models for estimating the seasonal variability of $\mathrm{N}$ and $\mathrm{P}$ fluxes at the sediment-water interface: application to the northwestern Adriatic coastal zone. J Mar Syst 87:239-255

Brigolin D, Meccia VL, Venier C, Tomassetti P, Porrello S, Pastres R (2014) Modelling biogeochemical fluxes across a Mediterranean fish cage farm. Aquacult Environ Interact 5:71-88

Brigolin D, Porporato EMD, Prioli G, Pastres R (2017) Making space for shellfish farming along the Adriatic coast. ICES J Mar Sci 74:1540-1551

Canu DM, Solidoro C, Cossarini GF (2010) Effect of global change on bivalve rearing activity and the need for adaptive management. Clim Res 42:13-26

Cloern JE (1982) Does the benthos control phytoplankton biomass in South San Francisco Bay? Mar Ecol Prog Ser 9:191-202

Cloern JE (1996) Phytoplankton bloom dynamics in coastal ecosystems: a review with some general lessons from sustained investigation of San Francisco Bay, California. Rev Geophys 34:127-168

Cloern JE (2001) Our evolving conceptual model of the coastal eutrophication problem. Mar Ecol Prog Ser 210:223-253

Cloern JE, Jassby AD (2010) Patterns and scales of phytoplankton variability in estuarine-coastal ecosystems. Estuar Coasts 33:230-241

Cloern JE, Nichols FH (1985) Time scales and mechanisms of estuarine variability, a synthesis from studies of San Francisco Bay. Hydrobiologia 129:229-237

Comeau LA, Filgueira R, Guyondet T, Sonier R (2015) The impact of invasive tunicates on the demand for phytoplankton in longline mussel farms. Aquaculture 441:95-105

Cranford P (2019) Magnitude and extent of water clarification services provided by bivalve suspension feeding. In: Smaal et al (eds) Goods and services of marine bivalves, Springer, Cham, pp 119-141

Cranford PJ, Strain PM, Dowd M, Hargrave BT, Grant J, Archambault M (2007) Influence of mussel aquaculture on nitrogen dynamics in a nutrient enriched coastal embayment. Mar Ecol Prog Ser 347:61-78

Cranford PJ, Li W, Strand Ø, Strohmeier T (2008) Phytoplankton depletion by mussel aquaculture: high resolution mapping, ecosystem modeling and potential indicators of ecological carrying capacity. ICES CM Document 2008/H:12. 5p. www.ices.dk/products/CMdocs/CM-2008/H/ H1208.pdf

Cranford PJ, Hargrave BT, Doucette LI (2009) Benthic organic enrichment from suspended mussel (Mytilus edulis) culture in Prince Edward Island, Canada. Aquaculture 292:189-196

Cranford P, Ward JE, Shumway SE (2011) Bivalve filter feeding: variability and the limits of the aquaculture biofilter. In: Shumway SE (ed) Aquaculture and the environment. Wiley, New York

Cugier P, Struski C, Blanchard M, Mazurié J, Pouvreau S, Olivier F, Trigui JR, Thiébaut E (2010) Assessing the role of benthic filter feeders on phytoplankton production in a shellfish farming site: Mont Saint Michel Bay, France. J Mar Syst 82:21-34

Dabrowski T, Lyons K, Curé M, Berry A, Nolan G (2013) Numerical modelling of spatio-temporal variability of growth of Mytilus edulis (L.) and influence of its cultivation on ecosystem functioning. J Sea Res 76:5-21

Dowd M (2005) A biophysical coastal ecosystem model for assessing environmental effects of marine bivalve aquaculture. Ecol Model 183:323-346 
Ferreira JG, Hawkins AJS, Bricker SB (2007) Management of productivity, environmental effects and profitability of shellfish aquaculture-the Farm Aquaculture Resource Management (FARM) model. Aquaculture 264:160-174

Filgueira R, Grant J, Strand Ø, Asplin L, Aure J (2010) A simulation model of carrying capacity for mussel culture in a Norwegian fjord: role of induced upwelling. Aquaculture 308:20-27

Filgueira R, Grant J, Stuart R, Brown M (2013) Ecosystem modelling for ecosystem-based management of bivalve aquaculture sites in data-poor environments. Aquacult Environ Interact 4:117-133

Filgueira R, Guyondet T, Comeau LA, Grant J (2014) Storm-induced changes in coastal geomorphology control estuarine secondary productivity. Earth's Futur 2(1):1-6

Filgueira R, Guyondet T, Bacher C, Comeau LA (2015) Informing marine spatial planning (MSP) with numerical modelling: a case-study on shellfish aquaculture in Malpeque Bay (Eastern Canada). Mar Pollut Bull 100:200-216

Grangeré K, Lefebvre S, Ménesguen A, Jouenne F (2009) On the interest of using field primary production data to calibrate phytoplankton rate processes in ecosystem models. Estuar Coast Shelf Sci 81:169-178

Grangeré K, Lefebvre S, Bacher C, Cugier P, Ménesguen A (2010) Modelling the spatial heterogeneity of ecological processes in an intertidal estuarine bay: dynamic interactions between bivalves and phytoplankton. Mar Ecol Prog Ser 415:141-158

Grant J, Filgueira R (2011) The application of dynamic modelling to prediction of production carrying capacity in shellfish farming. In: Shumway SE (ed) Shellfish culture and the environment. Wiley-Blackwell, New York

Grant J, Enright CT, Griswold A (1990) Resuspension and growth of Ostrea edulis: a field experiment. Mar Biol 104:51-59

Grant J, Dowd M, Thompson K, Emerson C, Hatcher A (1993) Perspectives on field studies and related biological models of bivalve growth and carrying capacity. In: Dame RF (ed) Bivalve filter feeders. NATO ASI series (Series G: ecological sciences), vol 33. Springer, Berlin/ Heidelberg

Grant J, Cranford P, Hargrave B, Carreau M, Schofield B, Armsworthy S, Burdett-Coutts V, Ibarra D (2005) A model of aquaculture biodeposition for multiple estuaries and field validation at blue mussel (Mytilus edulis) culture sites in eastern Canada. Can J Fish Aquat Sci 62:1271-1285

Grant J, Bugden G, Horne E, Archambault M-C, Carreau M (2007) Remote sensing of particle depletion by coastal suspension-feeders. Can J Fish Aquat Sci 64:387-390

Grant J, Bacher C, Cranford PJ, Guyondet T, Carreau M (2008) A spatially explicit ecosystem model of seston depletion in dense mussel culture. J Mar Syst 73:155-168

Guyondet T, Comeau LA, Bacher C, Grant J, Rosland R, Sonier R, Filgueira R (2015) Climate change influences carrying capacity in a coastal embayment dedicated to shellfish aquaculture. Estuar Coasts 38:1593-1618

Jiang T, Chen F, Yu Z, Lu L, Wang Z (2016) Size-dependent depletion and community disturbance of phytoplankton under intensive oyster mariculture based on HPLC pigment analysis in Daya Bay, South China Sea. Environ Pollut 219:804-814

Kach DJ, Ward JE (2008) The role of marine aggregates in the ingestion of picoplankton-size particles by suspension-feeding molluscs. Mar Biol 153:797-805

Kang CK, Lee YW, Choy EJ, Shin JK, Seo IS (2006) Microphytobenthos seasonality determines growth and reproduction in intertidal bivalves. Mar. Ecol Prog Ser 315:113-127

Lovato T, Androsov A, Romanenkov D, Rubino A (2010) The tidal and wind induced hydrodynamics of the composite system Adriatic Sea/Lagoon of Venice. Cont. Shelf Res 30:692-706

Lucas LV, Koseff JR, Monismith SG, Cloern JE, Thompson JK (1999a) Processes governing phytoplankton blooms in estuaries. II: the role of horizontal transport. Mar Ecol Prog Ser 187:17-30

Lucas LV, Koseff JR, Cloern JE, Monismith SG (1999b) Processes governing phytoplankton blooms in estuaries. I: the local production-loss balance. Mar Ecol Prog Ser 187:1-15

Ludvigsen M, Sørensen A (2016) Towards integrated autonomous underwater operations for ocean mapping and monitoring. Annu Rev Control 42:145-157

May CL, Koseff JR, Lucas LV, Cloern JE, Schoellhamer DH (2003) Effects of spatial and temporal variability of turbidity on phytoplankton blooms. Mar Ecol Prog Ser 254:111-128 
McKindsey CW, Thetmeyer H, Landry T, Silvert W (2006) Review of recent carrying capacity models for bivalve culture and recommendations for research and management. Aquaculture 261:451-462

Meeuwig JJ (1999) Predicting coastal eutrophication from land-use: an empirical approach to small non-stratified estuaries. Mar Ecol Prog Ser 176:231-241

Nielsen P, Cranford PJ, Maar M, Petersen JK (2016) Magnitude, spatial scale and optimization of ecosystem services from a nutrient extraction mussel farm in the eutrophic Skive Fjord, Denmark. Aquacult Environ Interact 8:311-329

Petersen JK, Holmer M, Termansen M, Hassler B (2019) Nutrient extraction through bivalves. In: Smaal et al (eds) Goods and services of marine bivalves, Springer, Cham, pp 179-208

Radiarta IN, Saitoh S-I (2009) Biophysical models for Japanese scallop, Mizuhopecten yessoensis, aquaculture site selection in Funka Bay, Hokkaido, Japan, using remotely sensed data and geographic information system. Aquac Int 17:403-419

Richardson AJ, Schoeman DS (2004) Climate impact on plankton ecosystems in the Northeast Atlantic. Science 305:1609-1612

Smaal AC, van Duren L (2019) Bivalve aquaculture carrying capacity: concepts and assessment tools. In: Smaal et al (eds) Goods and services of marine bivalves, Springer, Cham, pp 451-483

Smaal AC, Schellekens T, van Stralen MR, Kromkamp JC (2013) Decrease of the carrying capacity of the Oosterschelde estuary (SW Delta, NL) for bivalve filter feeders due to overgrazing? Aquaculture 404-405:28-34

Sonier R, Filgueira R, Guyondet T, Tremblay R, Olivier F, Meziane T, Starr M, LeBlanc AR, Comeau LA (2016) Picophytoplankton contribution to Mytilus edulis growth in an intensive culture environment. Mar Biol 163:73

Thomas Y, Mazurié J, Alunno-Bruscia M, Bacher C, Bouget J-F, Gohin F, Pouvreau S, Struski C (2011) Modelling spatio-temporal variability of Mytilus edulis (L.) growth by forcing a dynamic energy budget model with satellite-derived environmental data. J. Sea Res 66:308-317

Ubertini M, Lefebvre S, Gangnery A, Grangeré K (2012) Spatial variability of benthic-pelagic coupling in an estuary ecosystem: consequences for microphytobenthos resuspension phenomenon. PLoS One 7

Waite L, Grant J, Davidson J (2005) Bay-scale spatial variation of mussels Mytilus edulis in suspended culture, Prince Edward Island, Canada. Mar Ecol Prog Ser 297:157-167

Wijsman JWM, Troost K, Fang J, Roncarati A (2019) Global production of marine bivalves. Trends and challenges for the future. In: Smaal et al (eds) Goods and services of marine bivalves, Springer, Cham, pp 7-26

Zhao L, ZhaoY XJ, Zhang W, Huang L, Jiang Z, Fang J, Xiao T (2016) Distribution and seasonal variation of picoplankton in Sanggou Bay, China. Aquacult Environ Interact 8:261-271

Open Access This chapter is licensed under the terms of the Creative Commons Attribution 4.0 International License (http://creativecommons.org/licenses/by/4.0/), which permits use, sharing, adaptation, distribution and reproduction in any medium or format, as long as you give appropriate credit to the original author(s) and the source, provide a link to the Creative Commons license and indicate if changes were made.

The images or other third party material in this chapter are included in the chapter's Creative Commons license, unless indicated otherwise in a credit line to the material. If material is not included in the chapter's Creative Commons license and your intended use is not permitted by statutory regulation or exceeds the permitted use, you will need to obtain permission directly from the copyright holder.

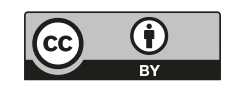

